\title{
Fundamental And Technical Factors Towards Investment Decisions And Company Value Moderated By Sales At Trading Companies In Indonesia
}

\author{
Mamay Komarudin \\ Fakultas Ekonomi dan Bisnis. Universitas Bina Bangsa Serang Indonesia \\ Corresponding author: \\ Email: Mamaykomarudin2014@gmail.com
}

\begin{abstract}
The purpose of this study is a) to analyze the influence of fundamental factors, namely profit growth, ROE and DER on investment decisions and value; to analyze the influence of macro factors namely sectoral PDP, SBI and exchange rate and beta of stocks on investment decisions and company value; to analyze the influence of technical factors i.e. the previous share price and trading volume on investment desperedness and the value of the company; to analyze the effect of investment decisions on the company's value; to analyze sales as moderating the effect of investment decisions on the value of the company. Based on the results of data analysis and discussion, it can be concluded that 1) fundamental factors as measured by profit growth, ROE and DER affect investment decisions; 2) Macro variables, namely interest rates and sectoral GDP, have a significant effect on investment decisions. That means higher macro variables are causing increases and decreases in investment decisions. While inflation has no positive and significant effect; 3) Technical variables consist of the previous share price and the trading volume has no significant effect on investment decisions. That means the higher the previous share price and the volume of trades does not increase investment decisions; 5) Fundamental factors namely profit growth, ROE and DER affect the value of the company; 6) Macro variables namely interest rates and sectoral GDP and inflation have no significant effect on the value of the company; 7) Investment decisions affect the value of the company; 8) In sales is not proven to moderate the mover of investment decisions against the value of the company.
\end{abstract}

Keywords: fundamentals, technical, macro, investment desperance and corporate value

\section{INTRODUCTION}

The capital market plays a strategic role in supporting national development as well as sources of financing and investment in addition to banking and foreign loans. The process of capital transactions takes place in a special market called a stock exchange. A capital owner must have an effective investment plan in order to make a profit in the capital market. One form of investment made by fund owners is to buy shares in the hope of obtaining the most optimal return in the form of dividends or capital gains. The existence of profit can remind the value of the company. Maximizing the value of the company is very important for a company, because by maximizing the value of the company means also maximizing the prosperity of shareholders who are the main objectives of the company (Martono and Harjito, 2013). Companies that consistently generate higher returns for their capital owners than they can get in alternative investment opportunities are valued at a higher market value. The company's market value can fluctuate over time in response to many factors that can be difficult or impossible to predict. 
There are several factors related to the value of the company. One of them is the investment decision made by the company. The value of the company is the perception of the owner of capital towards the success rate of the company that is often associated with investment decisions. The company's investment activities are the hardest decision for the management of the company because it will affect the value of the company (Vranakis and Prodmoros, 2014). The purpose of investment decisions is to earn a large profit with risks that can be managed in the hope of optimizing the value of the company. Investment decisions have a significant effect on the value of the company shows that there are a number of investments that will get a surplus if the company is able to make the right investment decisions. The surplus obtained will contribute to cash inflow, then accumulated on the increase in the company's profit. As a result of the above will have consequences for the problem, the owner of the capital makes the wrong decision so that the shares in question are judged incorrectly and often the market seems to be fooled by the information that must be interpreted. In addition, investment decisions give the behavior of capital owners who behave more based on the opinion of the heart so that investment decisions are subject to a lot of high risk.

Agency theory describes the relationship between shareholders as principals and management as agents. Management is a party contracted by shareholders to work for the benefit of shareholders. Since they were elected, the management must account for all their work to the shareholders. The agency theory has a role as the basis of business practices carried out to increase the value of the company and provide prosperity to the principal. The theory relates to the behavior of agents who are more selfish than for the benefit of shareholders in terms of this decision making. An agency relationship is a contract in which one or more people (principals) command another person (agent) to perform a service on behalf of the principal and authorize the agent to make the best decision for the principal. If both parties have the same goal to maximize the value of the company, then it is believed that the agent will act in a manner that is in accordance with the interests of the principal.

Potential agency problems occur if the manager's shareholding in the company's shares is less than one hundred percent. The existence of a proportion of ownership that is only part of the company makes managers tend to act for personal gain and not to maximize the company. This is what will cause agency costs. Based on the opinion of agency theory, conflicts between principals and agents can be reduced by aligning interests between principals and agents. The presence of stock ownership by managerial (insider ownership) can be used to reduce the agency cost that could potentially arise, because by owning the company's shares it is expected that the manager feels directly the benefits of every decision he made. This process is called the bonding mechanism, which is a process to equalize the interests of management through a binding management program in the company's capital.

Conflicts of interest in a company between principals and agents can arise due to excess cash flow. Excess cash flow tends to be invested in things that have nothing to do with the company's main activities. This leads to differences of interest because shareholders prefer high-risk investments that also generate high returns, while management prefers lower risk investments.

This research uses investments judging by the value of investments invested by the owner of capital in the company. Investment decisions from capital owners are measured by the value of investments invested in large trading and retail companies. Investment decisions relate to the value of the company.

This study uses investment decisions that are assessed to have an effect on the value of the company. This is because the increase in investment decisions will have an impact on increasing the value of the company. If the investment decision is higher, the influence of financial performance on the company's value will be higher. Signal theory that suggests how a company should give signals to users of financial statements. This signal is in the form of information about what has been done by the management to realize the wishes of the owner. Signals can be promotions or other information stating that the company is better than other companies. According to Brigham and Houston (2015), 
Signal theory is the company's action in signaling to capital owners about how management views the company. Signal theory discusses how signals of success or failure of management (agent) are conveyed to the principal. The encouragement in giving signals arises because of the asymmetric information between the company (management) and outside parties, where the owner of the capital knows the company's internal information relatively less and slower than the management.

The company's value can be increased by reducing asymmetric information, by signaling to outside parties in the form of reliable financial information so as to reduce uncertainty about the company's future growth prospects. A good financial statement will increase the value of the company. In signalling theory, management hopes to give a signal of prosperity to owners or shareholders in presenting financial information. The publication of the annual financial statements presented by the company will be able to signal dividend growth as well as the development of the company's share price. Several factors influence the ups and downs of the company's value, one of which is fundamental factors, technical factors and macro factors. Fundamental factors significantly affect the value of the company. Fundamental factors as measured by financial performance can increase the value of the company. Financial performance is an overview of the company's financial condition in a certain period concerning aspects of fund raising and fund distribution, which is usually measured by indicators of capital adequacy, liquidity, and profitability.

One of the interesting traits of financial or stock data behavior is its randomness to changes in value, even though it has a high volalitas and has a high frequency and volume of transactions. Although it does not show pure randomity, prediction of a particular data value is very difficult. This will be slightly helped if the trader is able to observe the pattern that arises from the behavior of the data. The study used previous stock price proxies and trading volumes in the assessment of technical factors. This proxy selection is based on empirical test results on research and technical assessment based on stock price and trading volume to be a benchmark of the company's success in increasing the value of the company. Technical factors as measured by trading volume significantly affect the value of the company. Stock trading volume is important for a capital owner, because the volume of stock trading describes the conditions of securities traded in the capital market. For owners of capital, before investing or investing the most important thing is the liquidity level of an securities (Wiyani and Wijayanto, 2010). In general, stocks that have a large market capitalization value become the target of capital owners for long-term investment because it illustrates the growth potential of a good company and has a low risk thereby increasing the value of the company.

Investment decisions related to the fundamentals and technicals of the company are fundamental factors related to investment decisions in relation to the measure of financial performance. Fundamental factors as measured by the analysis of financial ratios carried out will provide information on the financial condition and financial performance of a company on which the capital owner's decision to make a decision to invest. In addition, macro factors such as sectoral Gross Domestic Product, Bank Indonesia Certificate, exchange rates and stock beta influence investment decisions. The movement of macroeconomic factors can be used to predict stock price movements, but each researcher uses different macroeconomic factors because there is no consensus on which macroeconomic factors affect the share price (Wulandari, 2010) of sectoral Gross Domestic Product, Bank Indoensia Sertificate, exchange rate and beta of stocks.

\section{METHOD}

Based on investment theory, rising inflation and interest rates will cause marginal cost of capital to rise. Rising marginal cost of capital will increase the company's burden, thus lowering the company's profit which will affect the value of the company. The concept of dissertation in it will produce can contribute to the development of science or theory of inventions. The association of macro, technical and fundamental factors to the company's value investment decisions is explained by 
various empirical and theories that link macro, fundamental, technical and export variables to the value of the company and investment decisions from investors such as Figure 1 below.

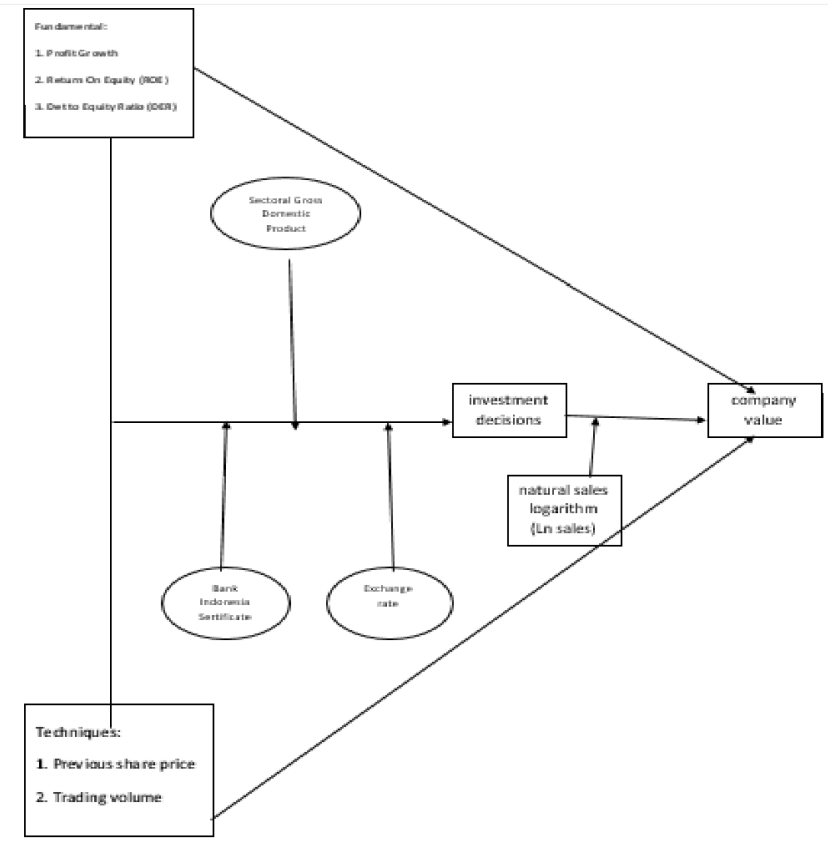

Fig 1. Conceptual Framework

The analysis steps that will be carried out in this study are as follows: Entering data, Planning the initial model to be formed using a path chart, Finding correlation values between variables, Calculating the size of the path coefficient, Testing the overall path coefficient, If an alternative model is obtained then a model feasibility test is carried out, Path analysis assumption testing, Determining the amount of indirect influence and total influence of each variable. The analysis in this study used panel data which is a combination of time-series data and cross-section data.

\section{RESULTS AND DISCUSSIONS}

\begin{tabular}{|c|c|c|c|c|c|}
\hline \multicolumn{2}{|c|}{ Variable } & \multirow{2}{*}{$\begin{array}{c}\begin{array}{c}\text { Coefficient of } \\
\text { regression }\end{array} \\
-521,098\end{array}$} & \multirow{2}{*}{$\begin{array}{l}t \text { count } \\
-4,155\end{array}$} & \multirow{2}{*}{$\begin{array}{c}\text { Significance } \\
0,000\end{array}$} & \multirow{2}{*}{$\begin{array}{l}\text { Description } \\
\text { Significant }\end{array}$} \\
\hline Investment & (Constant) & & & & \\
\hline \multirow[t]{10}{*}{ decisions } & $\begin{array}{l}\text { Profit Growth } \\
\text { (X1) }\end{array}$ & 0,039 & 3,491 & 0,024 & Significant \\
\hline & ROE (X2) & 0,014 & 2,158 & 0,034 & Significant \\
\hline & $\operatorname{DER}(\mathrm{X} 3)$ & $-0,263$ & $-3,331$ & 0,001 & Significant \\
\hline & interest $(\mathrm{X} 4)$ & $-0,220$ & $-2,111$ & 0,037 & Significant \\
\hline & Inflation (X5) & 0,093 & 0,866 & 0.388 & $\begin{array}{c}\text { Not } \\
\text { Significant }\end{array}$ \\
\hline & GDP (X6) & $0,43.1$ & 5,023 & 0,000 & Significant \\
\hline & $\operatorname{HSB}(\mathrm{X} 7)$ & $0,03.6$ & 0,316 & 0,753 & $\begin{array}{c}\text { Not } \\
\text { Significant }\end{array}$ \\
\hline & $\begin{array}{l}\text { Trading } \\
\text { volume (X8) }\end{array}$ & $-0,082$ & $-0,978$ & 0,330 & $\begin{array}{c}\text { Not } \\
\text { Significant }\end{array}$ \\
\hline & $\begin{array}{l}\text { Natural Sales } \\
\text { Logarithrn } \\
\text { (Ln sales) } \\
\text { (X9) }\end{array}$ & $-0,023$ & $-0,246$ & 0,806 & $\begin{array}{c}\text { Not } \\
\text { Significant }\end{array}$ \\
\hline & Moderate & 0,004 & 0,034 & 0,973 & $\begin{array}{c}\text { Not } \\
\text { Significant }\end{array}$ \\
\hline
\end{tabular}




\begin{tabular}{|c|c|c|c|c|c|}
\hline Company & (Constant) & $-521,737$ & $-4,138$ & 0,000 & \\
\hline \multirow[t]{11}{*}{ value } & $\begin{array}{l}\text { Profit Growth } \\
\text { (X1) }\end{array}$ & 0,039 & 3,491 & 0,024 & Significant \\
\hline & $\operatorname{ROE}(\mathrm{X} 2)$ & 0,014 & 3,159 & 0,004 & Significant \\
\hline & $\operatorname{DER}(\mathrm{X} 3)$ & $-0,263$ & $-3,304$ & 0,001 & Significant \\
\hline & Interest $(\mathrm{X} 4)$ & $-0,220$ & $-2,101$ & 0,038 & Significant \\
\hline & Inflation (X5) & 0,095 & 0,866 & 0,388 & $\begin{array}{c}\text { Not } \\
\text { Significant }\end{array}$ \\
\hline & GDP (X6) & 0,431 & 5,003 & 0,000 & Significant \\
\hline & HSB $(\mathrm{X} 7)$ & 0,038 & 0,328 & 0,744 & $\begin{array}{c}\text { Not } \\
\text { Significant }\end{array}$ \\
\hline & $\begin{array}{l}\text { Trading } \\
\text { volume (X8) }\end{array}$ & $-0,082$ &,- 0977 & 0,330 & $\begin{array}{c}\text { Not } \\
\text { Significant }\end{array}$ \\
\hline & $\begin{array}{l}\text { Natural Sales } \\
\text { Logarithm } \\
\text { (Ln sales) } \\
\text { (X9) }\end{array}$ & $-0,024$ & $-0,256$ & 0,798 & $\begin{array}{c}\text { Not } \\
\text { Significant }\end{array}$ \\
\hline & Moderate & 0,022 & 0,105 & 0,917 & $\begin{array}{c}\text { Not } \\
\text { Significant }\end{array}$ \\
\hline & $\begin{array}{l}\text { Investment } \\
\text { (Z) }\end{array}$ & $-0,021$ & 2,103 &, 018 & Significant \\
\hline
\end{tabular}

Table 2. Path Coefficient value and Hypothesis Testing Description : $* *=$ Significant on $\alpha=5 \%$

After the classical assumption test, hypothesis testing of each path is carried out. Based on the results of the data analysis shows variables that have a significant effect on investment decisions are Profit Growth, ROE, DER, Interest rates and GDP. But variable Inflation, HSB, Trading volume and In Sales have no significant effect on investment decisions.

While profit growth, ROE, DER, interest rates, GDP and investment decisions affect the value of the company. While inflation, HSB, Trading Volume and Ln Sales have no significant effect on the value of the company. In sales can not moderate the investment desperation towards the value of the company.

The test results showed that the fundamental factors measured by profit growth proved to have a significant effect on investment sedation. It shows the higher the return it will increase investment decisions. Based on the test results show that profitability has a positive and significant effect on investment decisions. Profitability proposed with ROE explained that any increase in profitability (ROE) will increase investment decisions. The higher ROE will increase investment decisions because it shows that the ability to manage ekulitas so as to generate high returns. That will give the owner the opportunity to increase his investment decisions.

Profitability is the ability to generate profit during a certain period by using assets or capital, both overall capital and own capital). Based on Ayuningtias's opinion (2013:6), stated that high profitability indicates a good company prospect, so that the owner of the capital will respond positively to the signal and the value of the company will increase.therefore, to obtain a high corporate value the need for management's ingenuity in making decisions where one of the important is investment decisions. With a good investment decision will be profitable for the company so as to maximize the value of the company.

Fundamental factors as measured by profitability can improve investment decisions. Signaling theory was built as an effort to improve investment decisions in the company. Signal theory indicates the existence of information asymmetry between the management of the company and the parties 
concerned with the information. Signal theory suggests how companies should give signals to users of financial statements, especially the owners of capital who will make investments.

This signal can be profitability information to realize the desire of the owner (Owner of capital) in investing. Signaling theory also explains why companies have a push to provide financial statements information, especially profit on internal parties. The company's push to provide such information is because there is asymmetry of information between the company and the owner of the capital because the company knows more about the company and future prospects than with outside parties. The signaling reportedly makes management conduct accrual policies that lead to an increase in the company's profit. Information that is a signal in the capital market will encourage management to present a profit report that can reflect real returns so as to improve investment decisions.

Leverage has a negative and significant effect on investment decisions. This means that any increase in leverage levels lowers investment decisions. Leverage in this study is explained by DER proxies where the company's funds are financed by debt. Companies that have high leverage mean that the company uses high debt so as to lower investment decisions. This is due to the large amount of debt held by the company due to fluctuations in the rupiah exchange rate against the dollar which resulted in the amount of the company's debt in rupiah to increase sharply. This makes the trust of the owners of capital decrease so that higher debt will decrease investment decisions.

Leverage yang diukur dengan DER, DER merupakan perbandingan total hutang yang dimiliki perusahaan dengan total ekuitas perusahaan dimana DER yang semakin tinggi akan menurunkan keputusan investasi perusahaan. Peningkatan Hutang yang digunakan oleh perusahaan akan menurunkan besarnya konflik keagenan antara pemegang saham dengan manajer. Berdasarkan pendapat Jensen (1986) penggunaan hutang akan menurunkan excess cash flow yang ada dalam perusahaan. Penurunan excess cash flow ini akan menurunkan kemungkinan pemborosan yang dilakukan oleh manajemen untuk hal-hal yang kurang perlu. Dengan begitu kas akan digunakan untuk hal-hal yang lebih produktif sehingga mempengaruhi keputusan investasi. Peningkatan penggunaan hutang dapat menekan free cash flows yang berlebihan dimana adanya arus kas perusahaan yang tidak diinvestasikan secara menguntungkan.

The test results showed macro variables measured by interest rates and sectoral GDP had a significant effect on investment decisions. This indicates that any increase in variable interest rates and sectoral GDP will drive up the company's investment decisions. The direction of the relationship of the results of this study is in line with the expected relationship direction in the hypothesis. While inflation has no significant effect on investment decisions.

Macro variables are measured by inflation, interest rates and the rupiah exchange rate against the dollar. Interest rate is a measure of investment profit that can be obtained by the owner of capital and is also a measure of the cost of capital that must be spent by the company to use funds from investors. Theoretically the relationship between interest rates and capital markets is negative or inversely proportional. If interest rates rise, it will cause the capital market to decline and vice versa if the interest rate falls, it will cause the capital market to increase. A rate hike will generally cause the share price to fall because it will cut the company's profits. This leads to increased investment from the capital market. Research supporting Tulong (2015) found that interest rates, inflation and economic growth influence investment decisions.

Inflation is caused by the increase in the price of goods and services in general and continuously. High inflation can also reduce the level of rill income that the owner earns from his investment. Conversely, if the inflation rate declines, this is a positive signal for capital owners as the risk of purchasing power of money decreases and the risk of a decrease in rill income. It is explained that inflation does not increase investment. This is because inflation illustrates the rate of increase in the price of goods in the community. The price level affects the number of offers and offers of money. Inflation causes people's purchasing power to be reduced because the same amount of money last year 
was unable to buy the same item this year. This causes the rupiah to depreciate so that it does not make investments increase. The results of this study do not support the assumption of economic theory that the movement of inflation has the potential to increase or decrease investment in the real sector. This means that macro conditions cannot increase or decrease the company's investment or investment decisions.

The results of this study are not in accordance with the economic theory of the influence of macro factors on investment decisions stating that the movement of inflation, interest rates, exchange rates and exports has the potential to increase or decrease investment in the real sector, and this will have an impact on the performance of capital markets, where investment in the capital market becomes more risky if volatility of movement is high. The study found that macro conditions had no impact on the company's investment decisions. It shows that each company does not feel the impact of changes in macro-economic factors even though each company has different impacts from inflation movements, interest rates, exchange rates and economic growth so that macro conditions do not have an impact on investment investment.

High low risk for companies does not affect from changes in macroeconomic conditions depending heavily on the internal condition of the company. A financially sound company may have a not so great impact, but for companies that are not healthy financial condition can happen otherwise. The company became difficult to move. develop its business, so that its performance will decrease. If so, then it is difficult for managers to increase the value of the company or the prosperity of its shareholders.

Sectoral GDP affects investment decisions because this is possible because sectoral GDP is the only consideration of capital owners in investing in the trade sector because other things that may be the consideration of capital owners in investing are low levels of labor wages and ease of licensing management so that it can be concluded that changes in interest rates are not elastic or inelastis to investment decisions in the trade sector. This is because the owners of capital are more aware and consider the risk factors that are reinforced by uncertainty factors that still affect future economic conditions. Many risk factors come from non-economic variables such as instability of political and security conditions, inefficient bureaucracy, low quality of human resources, and poor infrastructure.

In addition, other macro variables including inflation do not affect investment decisions. Inflation has a negative impact on investment activities in the form of high investment costs. High inflation of a country will decrease the interest of capital owners in investing due to high investment costs. Conversely, the cost of investment will be cheaper if the inflation rate of a country is low and will increase investment in Indonesia. The results of this study show that inflation variables do not affect investment decisions.

The previous share price had no significant effect on investment decisions. This indicates that any decrease from the previous share price growth rate will not increase the growth rate of investment decisions. The prior share price cannot be a consideration for investment decisions for the company. The previous share price had no effect on investment decisions. That means the share price is not used as a measure of investment decisions for owners of capital. Previous share prices that were not the benchmark for making investment decisions were not only taken into account with the stock price history but saw the daily share price developments that were a consideration for the owners of the capital.

There is a recurring price pattern back in the future. Patterns of stock price movements based on observations of past price movements do not improve investment decisions. If a company offers the sale of new shares more often than usual, then its share price will decline, because issuing new shares means giving a negative signal that can then depress the share price as well as bright company prospects. A signal or signal is an action taken by the company to provide guidance to the owner of capital about how management views the company's prospects. This signal is in the form of 
information about what has been done by the management to realize the wishes of the owner. Information released by the company is important, because of its influence on investment decisions of parties outside the company. Such information is important for capital owners and businesses. Because the information in effect presents information, notes or descriptions, both for past, current and future circumstances for the company's survival and how it will affect the company.

The results showed that the volume of stock trading has no effect on investment decisions. That means the higher the volume of stock trading will give rise to the trust of the owner of capital for investment. The higher trading volume is not able to increase investment desperation.

Investment decision is a decision issued by the company related to the company's activities to release funds at this time in the hope of generating future fund flows with a greater amount than released at the time of the initial investment, so that the company's expectations to always grow and develop will be more clear and planned. Investment decisions can be grouped into short-term investments such as investments in cash, inventories, receivables and securities while long-term investment decisions such as buildings, production equipment, land, vehicles and other fixed assets. This investment decision will be reflected in terms of assets in the company's balance sheet. Investment decision is the first step to determine the amount of assets needed by the company as a whole so that this investment decision is the most important decision made by the company. Investment decisions of course require the owners of capital to analyze the trading volume of shares experienced by the company.

Profit growth affects the value of the company. It shows that the higher the profit, the higher the value of the company. Likewise. ROE has a positive and significant effect on the company's value. It shows that the higher the company's profit capability, the higher the value of the company. The direction of positive relationships in the results of this study is in line with the expected relationship direction in the hypothesis. The ability to profit that increases the value of the company becomes even higher.

Leverage promoted with DER has a significant effect on the company's value. It shows that high debt usage can increase the value of the company. High or low debt can increase or decrease the value of the company. The results of the study explain that DER has a significant effect on the value of the company. This is because the use of debt in the company's asset structure does not affect the value of the company through interest tax savings that reduce after tax cost of capital. In other words, if there is a corporate income tax does not affect the value of the company will increase because the cost of debt interest is a cost that reduces tax deductable expense (Modigliani and Miller in Brigham, 1999:34).

Macro variables have no significant effect on company value. This indicates that any increase in macro variables will not increase or decrease the company's value. It shows that macro conditions such as inflation, interest rates and exchange rates have no effect on the value of the company.

The increase in the value of the company as measured by Price earning Ratio (PER) is not influenced by macro variables such as interest rates, inflation and exchange rates but is more likely to be on the external condition of the company. PER is considered by the owners of capital in determining which shares to buy, because PER indicates the achievements and prospects of a company. Basically PER can not be directly paid in cash to the owner of capital. Earnings will be returned in the form of dividends and an increase in the share price of the retained share of the earnings. Companies with low PER often provide their own attractiveness for owners of capital to buy it. Of course the PER value cannot be separated from other information or other conditions such as macro conditions. The main purpose of a company based on the opinion of theory of the firm is to maximize the wealth or value of the company. The value of the company is the perception of the owner of capital to the success of the company, the high value of the company will make the market believe in the company's performance and management performance in managing the company as 
well as the promising prospects of its ability in the future in improving the prosperity of the owners of capital.

High interest rates can increase the cost of capital which can further lower the company's profit, while the expected return expectations for owners of high capital are met by the issuer. This condition will definitely affect the value of the company. Interest rates are monetary policy aimed at suppressing inflation growth, if inflation conditions are normal then interest rates will fall so that the cost of capital for companies will also be reduced. In addition, depreciation of foreign currency value indicates that the trade balance is positive, the increase in export commodities causes the rupiah exchange rate to weaken but has no impact on the value of the company.

Test results showed that the previous share price had no significant effect on the company's value. It shows that if the previous price rises then the value of the company will not increase or decrease. The previous share price had no effect on value meaning it could not increase the PER value that was a proxy for the company's value in this study. That is because the company's high value will be followed by the high prosperity of shareholders more can be seen from the share price that applies when the investment decision is taken by the owner of the capital. The value of the company is the expected future profit value that is recalculated at the right interest rate so that the prevailing share price at the time of sale or purchase is more likely to affect the value of the company.

The test results showed that the trading volume had no positive and significant effect on the company's value. This result shows that the higher the volume of stock trading, the higher the value of the company. Hugida (2011:2) stated that volume has no effect on the value of the company because the volume reflects the information received by market participants, the information causes a positive relationship between the volume and value of the company.

Stock trading volume is important for a capital owner, because for the owner of capital the volume of stock trading describes the condition of shares traded in the capital market that can have an impact on the share price (Fauziah, 2013:2). The volume of stock trading is determined by demand and supply. This approach emphasizes the importance of future capital owners' behavior and is based on the past, so that analysts study stock price changes using historical trading data.

Investment decisions made with asset growth have a positive and significant effect on the company's value as measured by PER. The higher the investment decision, the higher the company's value. If the higher the investment in the company then the value of the company will also increase. The company's value in this study was measured by a Price earning ratio (PER) that showed how much money owners were willing to spend to pay each dollar of reported earnings (Brigham and Houston, 2006).

Investment decisions must allocate funds into forms of investment that will be able to bring profit in the future. Investment decisions are the most important of the two other policies in financial management, namely funding decisions and dividend policies. Capital investment as the main aspect of financial management policy because investment is a form of capital allocation whose realization must produce benefits or profits in the future.

Investment Decisions against Company Value with Ln Sales as moderation have not proved significant. It showed that while the sale could not improve its decision to divest against the company's value. The Price Earning Ratio in this study looked at how the market appreciates the performance of companies reflected by their earnings per share. Price earning ratio shows the relationship between ordinary stock market and earning per share. Price earning ratio (PER) serves to measure changes in the ability of expected earnings in the future. The greater the PER, the greater the possibility of the company to grow so as to increase the value of the company.

Investment decisions concerning the decision of the allocation of funds both from within the company and funds coming from outside the company in various forms of investment. 


\section{CONCLUSION AND SUGGESTION}

Based on the results of data analysis and discussion, it can be concluded that 1) fundamental factors as measured by profit growth, ROE and DER affect investment decisions; 2) Macro variables, namely interest rates and sectoral GDP, have a significant effect on investment decisions. That means higher macro variables are causing increases and decreases in investment decisions. While inflation has no positive and significant effect; 3) Technical variables consist of the previous share price and the trading volume has no significant effect on investment decisions. That means the higher the previous share price and the volume of trades does not increase investment decisions; 5) Fundamental factors namely profit growth, ROE and DER affect the value of the company; 6) Macro variables namely interest rates and sectoral GDP and inflation have no significant effect on the value of the company; 7) Investment decisions affect the value of the company; 8) In sales is not proven to moderate the mover of investment decisions against the value of the company.

\section{REFERENCES}

[1] Ayuningtyas, Dwi 2013. 'Pengaruh Profitabilitas Terhadap Nilai Perusahaan: Kebijakan Dividen dan Kesempatan Investasi Sebagai Variabel Antara' Jurnal.STIESIA Surabaya Vol 2 no 1.

[2] Ariska, M., \& Fahru, M. (2020). Leverage, Ukuran Perusahaan dan Profitabilitas dan Pengaruhnya Terhadap Tax Avoidance Pada Perusahaan Sektor Pertambangan di Bursa Efek Indonesia Tahun 20142019. Jurnal Revenue: Jurnal Ilmiah Ilmu Akuntansi, 1(1), 133-142.

[3] Brigham, Eugene F and Houston, Joel F. 2015. Dasar-Dasar Manajemen. Keuangan, alih bahasa Ali Akbar Yulianto, Buku satu, Edisi sepuluh, PT. Salemba

[4] Cheung, William Mingyan, Richard Chung dan ScottFung. 2015. The Effects Of Stock Liquidity On firm Value and Corporate Governance: Endogeneity and The REIT experiment. Journal Coorparate Finance. Pg. 231-232

[5] Devianasari, N luh \& Ni Putu,s 2015. 'Pengaruh PER, DER, dan DPR terhadap nilai perusahaan pada perusahaan manufaktur yang terdaftar di BEI'. E- jurnal manajemen universitas Udayana vol 4 no 11

[6] Efni, Yulia. 2017. 'The mediating effect of investment decisions and financing decisions on the effect of corporate risk and devidend policy against corporate value'. Investment management and financial innovations, vol 14 issue 2.

[7] Ekman Nils, 2017.An Empirical Analysis of the Profitability of Technical Analysis Across Global Markets The Case of Equities, Commodities and Foreign Exchange Rates Lund University School Economics And Management

[8] Fahmi, Irham 2012. Analisa Laporan Keuangan.Cetakan ke -2. Bandung :Alfabeta. 2012

[9] Fahmi, Irham 2014. Analisa Laporan Keuangan. Cetakan ke -2. Bandung :Alfabeta. 2012

[10] Handayani Sri dan Artini. 2013. Pengaruh Rasio Keuangan Daerah terhadap Belanja Modal untuk Pelayanan Publik dalam Perspektif Teori Keagenan (Studi pada Kabupaten dan Kota di Jawa Tengah)". JurnalEkonomi

[11] Harahap, Sofyan S 2013. Analisis Kritis Atas Laporan Keuangan. Raja Grafindo Persada, Jakarta.

[12] Harmono, 2017Manajemen Keuangan Berbasis Balanced Scorecard. (Pendekatan Teori,

[13] Hasania. Zuhria ,Murni, S \& Mandagie, 2016. 'Pengaruh Current ratio, ukuran perusahaan, struktur modal dan RoE terhadap Nilai perusahaan Farmasi yang terdaftar di bursa efek indonesia periode 2011 2014'. Jurnal berkala ilmiah efesiensi vol 16 no 3

[14] Hemastuti, Candra Pami. 2014. Pengaruh Profitabiltas, Kebijakan Dividen, Kebijakan Hutang, Keputusan Investasi dan Kepemilikan Insider Terhadap Nilai Perusahaan.Jurnal Ilmu \& Riset Akuntansi Vol. 3 No. 4

[15] Hermawan, Ahmadi, 2013. E-Business \& E-Commerse. Andi: Denpasar.

[16] Hermuningsih, Sri dan Dewi Kusuma Wardani. 2013 Faktor-Faktor yang Mempengaruhi Nilai Perusahaan pada Perusahaan yang Terdaftar di Bursa Efek Malaysia dan Bursa Efek Indonesia. Jurnal Siasat Bisnis, Vol. 13, No. 2, pp. 173-183 
[17] Jagongo dan Vincent S. Mutswenje.2014. A Survey of the Factors Influencing Investment Decisions: The Case of Individual Pemilik modals at the NSE Ambrose. International Journal of Humanities and Social Science Vol. 4 No. 4 [Special Issue-February 014] 92

[18] Kandir, Serkan Yilmaz. Arioglu, Emrah. 2014. Investigating The Impact of Microeconomic Factors on Stock Return: Evidence From Borsa Istanbul. Journal of Economics and Management. HIm 1-14

[19] Kasmir, 2008. Bank dan Lembaga Keuangan Lainnya. Edisi Revisi 2008. Jakarta: PT. RAJAGRAFINDO PERSADA

[20] Kotwani, K. 2016. Financing Constraints and Corporate Investment. Brookings Paper on Economic Activity, 1.141-206

[21] Kumar, S., dan Warne, D. 2014. Parametric Determinants of Price-Earnings Ratio in Indian Capital Markets. The IUP Journal of Applied Finance, 15(9), 63-82.

[22] Kusumaningrum, Ayu L 2016. 'The effeect of return on equity (ROE) to corporate value with managerial ownership as a moderating variabel( a study at manufacturing companies listed in indonesia stock exchange)'.Artikel Ilmiah mahasiswa Universitas Jember.

[23] Lestari Raisa Ayu, 2016. Factor-Faktor Yang Mempengaruhi Nilai Perusahaan. Jounal Ilmiah Universitas Bakrie, vol 1. No 2. 2013

[24] Mahastanti. Linda Ariany 2011. Faktor - faktor yang mempertimbangkan pemilik modal dalam melakukan investasi”. Jurnal Manajemen Teori dan Terapan| Tahun 4, No. 3, Desember

[25] Martono dan, Harjito, Agus. 2011Manajemen Keuangan,edisil.yogyakarta: EKONISIA

[26] Maulina et al. 2018. . The Impact of Technical Analysis on Stock Returns in an Emerging Capital Markets (ECM's) Country: Theoretical and Empirical Study International Journal of Economics and Finance; Vol. 9, No. 3

[27] Oktavia, V., Jefri, U., \& Kusuma, J. W. (2020). Pengaruh Good Corporate Governance dan Ukuran Perusahaan Terhadap Tax Avoidance. Jurnal Revenue: Jurnal Ilmiah Ilmu Akuntansi, 1(2), 143-151.

[28] Petrusheva, Nada dan Jordanoski, Igor.2016. Comparative Analysis Between The Fundamental And Technical Analysis Of Stocks. Journal of Process Management - New Technologies, International Vol. 4, No.2

[29] Prasetyo, Zahroh Z.A dan Devi Farah Azizah.2011. Pengaruh Keputusan investasi Dan Keputusan Pendanaan Terhadap Nilai Perusahaan (Studi pada Perusahaan Sektor Properti dan Real Estate yang Terdaftar di BEI Periode Tahun 2009-2011). Jurnal Ekonomi Volume 4 Hal.1-8

[30] Putra Nyoman Wedana Adi, 2014. Pengaruh Faktor Fundamental Pada Nilai Perusahaan Sektor Telekomunikasi Di Bursa Efek Indonesia Jurnal Ekonomi Volume 3 Hal.1-11

[31] Rakhimsyah dan Gunawan.2011. "Pengaruh Keputusan Investasi, Keputusan Pendanaan, Kebijakan Dividen dan Tingkat Suku Bunga TerhadapNilai Perusahaan”.Jurnal Investasi Vol. 7 No.1 Juni 2011.

[32] Ramadhany, Fika. 2015. Pengaruh CR, QR, DAR, DER, Dan ROE Terhadap Nilai Perusahaan( Studi Empiris Pada Perusahaan Farmasi Yang Terdaftar Di BEI Periode 2011-2014)'. Jurnal Universitas Widyatama Vol 1 No 2. Research Journal Of Finance And Accounting. Vol.9, No.3

[33] Rismawati, 2012, Analisis Perbandingan Model Prediksi Financial Distress. Jurnal Ekonomi Indonesia

[34] Riyanto, Bambang.2011.Dasar-dasar Pembelanjaan Perusahaan. BPFE, Yogyakarta

[35] Robinhot, Gultom, Agustina, dan Sri Widia Wijaya. 2013,Analisis Factor-Faktor Yang Mempengaruhi Nilai Perusahaan Pada Perusahaan Farmasi Dibursa Efek Indonesia, Jurnal Wira Ekonomi Mikroskil vol 3 no 1. April.2013

[36] Simarmata, Rhoma dan Subowo.2016.Pengaruh Intellectual Capital terhadap Kinerja Keuangan dan Nilai Perusahaan Perbankan Indonesia. Accounting Analysis Journal 5 (1), ISSN: 2252-6765

[37] Sugeng, Sulistiono et. al 2017. Investment opportunity set as the mediation effect of capital structure, and corporate dividend policy on firm value : A study on manufacturing firms in indonesia stock exchange. International journal of applied Busniness and economic research vol 15 no 22.

[38] Suresh. A.S,.2013. A Study on Fundamental and Technical Analysis. International Journal of Marketing, Financial Services \& Management Research ISSN 2277- 3622 Vol.2, No. 5

[39] Todaro, Michael. 2006 Pembangunan Ekonomi Di Dunia Ketiga, Edisi. Keenam, Jakarta: Erlangga. 
[40] Tulay Yucel dan Guluzar Kurt. 2014. Foreign Exchange Rate Sensitivity And Stock Price:Estimating Economic Exposure Of Turkish Companies. Turkey Business Administration Accounting and Finance Department

[1] Voloshyna, K. 2015. Fundamental Analysis Vs Technical Analysis in The Egyptian Stock ExchangeEmpirical Study. International Journal of Business and Management Study-IJBMS,2(2), 212- 218

[41] Wahyudi, Untung \& Pawestri, H 2006 . 'Implikasi Struktur Kepemilikan Terhadap Nilai Perusahaan Keputusan Keuangan Sebagai Variabel Intervening’. Simposium Nasional Akutansi IX. Padang

[42] Wijaya, Bayu \& Bandi, Sedana, I 2015. 'Pengaruh Profitabilitas Terhadap Nilai Perusahaan (Kebijakan Dividen Dan Kesempatan Investasi Sebagai Variabel Mediasi)'. E- jurnal manajemen Unud, vol 4 no 12. 